\title{
Cross-border cooperation in the execution of sentences between the Netherlands, Germany and Belgium: an empirical and comparative legal study on the implementation of EU framework decisions 2008/909/JHA and 2008/947/JHA
}

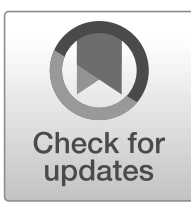

\section{Robin Hofmann ${ }^{1} \cdot$ Hans Nelen ${ }^{1}$}

Published online: 14 May 2020

(C) The Author(s) 2020

\begin{abstract}
This study aims at comparing legal practices in the execution of sentences within the framework of cross-border cooperation between The Netherlands, Belgium and Germany. Based on quantitative and qualitative data, the implementation of the EU Framework Decisions 2008/909/JHA on the transfer of prisoners and 2008/947/JHA on the mutual recognition of judgments and probation decisions in the three countries is analyzed. Interview data with legal practitioners suggest that social rehabilitation, consents of the convicted individuals and the actual place of living, play an important role in the initiations of transfers. Empirical evidence that both Framework Decisions are increasingly instrumentalized for migration control purposes, as the current scientific debate suggest, is weak in the three case countries. The relatively small numbers of transfers of prisoners and judgements show, that the transfer instrument is still not implemented to its full potential. This study exemplifies remaining challenges connected to the principle of mutual trust in the daily practice of cross-border legal cooperation within the EU.
\end{abstract}

Keywords Comparative criminal law $\cdot$ Penology $\cdot$ Cross-border cooperation · Sentencing · Crimmigration $\cdot$ Prison population $\cdot$ Prisoner transfer

Robin Hofmann

robin.hofmann@maastrichtuniversity.nl

1 Department of Criminal Law and Criminology, Faculty of Law, Maastricht University, Bouillonstraat 1-3, 6211 LHMaastricht, The Netherlands 


\section{Introduction}

Cross-border cooperation in criminal legal matters between the Netherlands, Belgium and Germany has a long tradition. This is particularly the case within the border region of these three neighbouring countries, also referred to as the Meuse-Rhine Euregion, one of Europe's most urbanised areas. It comprises the Dutch and Belgian provinces of Limburg - including the cities of Maastricht, Liege, Eupen, Hasselt, and on the German side, the State of North-Rhine Westfalia (NRW) with the Aachen Region [1]. Divided by three country borders, cross-border criminality and security problems related to a wide range of crime phenomena, occur in a concentrated manner [2]. Legal cooperation between law enforcement authorities remains challenging, partly due to different languages, legal cultures, as well as visible and non-visible barriers that shape the implementation of shared governance [3]. Consequently, the EU Commission refers to border regions (or Euro-regions) as the 'laboratories of European integration' [4].

Over the years, the Euregion, but also the aforementioned three neighbouring countries, have been the subject of numerous scientific studies on issues of legal cooperation and legal comparison (e.g. [1-3, 5-9]). However, comparative and empirical research on the execution of sentences between the three countries is scarce. This comes as no surprise since the execution phase of the criminal law enforcement cycle has been somewhat ignored by criminologists and policymakers [10,11]. The public assumes all too readily that most sentences are executed in accordance with court decisions. But empirical studies reveal that due to logistical and organisational problems, the execution of sentences is by no means self-evident [12]. In 2010 for instance, the short-term prison sentences of 2600 people in the Netherlands could not be executed because the limitation period had expired [13]. The main problem that the criminal justice system faced in these cases was that the convicted persons did not report themselves and could not be tracked down. In Germany, a similar situation enfolds: according to the State Police Office of NRW, the number of open arrest warrants amounted to over 23,000 in the year 2015. In 7700 cases alone, open warrants were issued against convicted persons who never showed up for their prison sentence, and, hence, managed to escape justice [14].

In many of these cases, the sentenced person avoids the execution of his or her sentence by crossing the border to a neighbouring country. A lack of oversight, legal cooperation and data sharing across borders remain EU-wide problems for law enforcement authorities. Framework Decision 2002/584/JHA on the European Arrest Warrant (EAW) is one of the well-known (and extensively researched) tools to prevent impunity as a result of crossing borders in the Schengen Area [15]. Less attention has been paid to the two 'younger siblings' of the EAW, the Framework Decisions 2008/909/JHA and 2008/947/JHA, both directly dealing with the execution of sentences ${ }^{1}$ :

\footnotetext{
${ }^{1}$ Another Framework Decision that is closely linked is 2009/829/JHA on the application of the principle of mutual recognition to decisions on supervision measures as an alternative to provisional detention (European Supervision Order). It only concerns provisional release in the pretrial stage and will not be dealt with in depth within this article.
} 
- Council Framework Decision 2008/909/JHA (in the following: FD 2008/909) on the application of the principle of mutual recognition to judgments in criminal matters imposing custodial sentences or measures involving deprivation of liberty. According to the European Commission [16], it allows, on the one hand, a Member State of the EU to execute a prison sentence issued by another Member State against a person who remains in the first Member State. On the other hand, it establishes a system for transferring convicted prisoners back to the Member State of nationality or habitual residence (or to another Member State with which the prisoners have close ties) to serve their prison sentence.

- Council Framework Decision 2008/947/JHA (in the following: FD 2008/947) on the application of the principle of mutual recognition to judgments and probation decisions with a view to the supervision of probation measures and alternative sanctions. According to the European Commission [16], this framework decision applies to many alternatives to custody and to measures facilitating early release. The probation decision or an alternative sanction can be executed in another Member State, as long as the person consents.

According to the European Commission [16], both framework decisions were drafted with the objective of ensuring that non-resident EU citizens, who are subject to criminal proceedings, are not treated differently from resident EU citizens. Moreover, both framework decisions have the potential to lead to a reduction in the number of prison sentences and pre-trial detention imposed on non-residential EU citizens. This in turn could reduce prison overcrowding, improve detention conditions, allow for considerable budgetary savings for prisons and facilitate social rehabilitation of prisoners in a cross-border context.

In the Netherlands and Belgium, the framework decisions were implemented in 2013, while Germany followed in 2015. Since then, especially the practices regarding prisoner transfers have gained the interest of researchers (examples include: [17-20]). Empirical studies, however, have remained relatively scarce, and so have comparative legal studies that deal with the implementation of the framework decision in legal practice $[21,22]$. The empirical study, which this article is based upon, was conducted to fill this gap in research. The goal of the study was to compare the legal practices regarding the execution of sentences within the framework of cross-border cooperation between the Netherlands, Belgium and Germany, and, particularly, to analyse the challenges and impediments in this respect. ${ }^{2}$ The first questions that will be addressed in this article are related to the rationale and extent of transferring judgements and sentences in the three countries. How often do prisoner transfers based on the framework decisions take place, and what are the main goals of applying the available instruments? In answering these questions, alongside quantitative data on transfer cases, demographical data on prison populations and transferred persons will be included in the analysis as well. The reason for including this type of data is related

\footnotetext{
The research was part of the project "Improving judicial cooperation in the field of Cross Border Execution of Sentences between Belgium (BE), Germany (DE) and the Netherlands (NL) and, in general, between all other EU-countries" ("CrossBes"). The CrossBes-project was funded by the European Commission, DG Justice and consumers, and was a cooperation between the Bureau Euregional Cooperation of the prosecution service and researchers of the faculty of Law of Maastricht University and the Catholic University Leuven (Belgium). The final conference of this project took place in Maastricht in September 2019.
} 
to concerns among scholars that prisoner transfers may be instrumentalised for migration control purposes, and for the deportation of unwanted migrants [19, 23, 24]. These concerns, voiced within the debate surrounding the concept of 'crimmigration', must be taken seriously within a comparative legal study that addresses the topic of prisoner transfers. After all, a misuse of prisoner transfers for deportation purposes has the potential to discredit the entire EU prisoner transfer system.

The second set of questions addressed in this article are centred around the implementation of FD 2008/909 and FD 2008/947 in the legal systems of the case countries. The focus will be on questions of how transfer cases are handled by the responsible authorities, which legal dynamics play a role, and which challenges occur in the daily practice of legal cross-border cooperation.

\section{Methodology}

The present study used a mixed method approach comprising a comparative legal and empirical analysis. The comparative legal analysis focused on Dutch, German and Belgian laws and legal practices related to the transfer of judgements and prisoners. The focus remained on processes and procedures, not only in the written law, but also in their implementation in daily legal practice. The empirical analysis comprises quantitative data on prison populations and transfer cases pursuant to FD 2008/909 ( $N=569)$ and FD $2008 / 947(N=138)$. The data was partly publicly available or provided by the Ministries of Justice of all three countries. ${ }^{3}$ The quantitative analysis was complemented by semi-structured interviews held with ten legal practitioners from Germany $(N=2)$, the Netherlands $(N=4)$, and Belgium $(\mathrm{N}=4)$. All interviewees have a professional background as prosecutors and are legal experts in the field of crossborder cooperation, with practical experience related to the transfer of judgements and prisoners. In addition, four focus group studies were conducted during a workshop on cross-border cooperation with regard to sentencing. ${ }^{4}$ Each group was composed of ten to fifteen Dutch, Belgian and German legal practitioners, adding up to 56 participants in total (21 from the Netherlands, 20 from Belgium and 15 from Germany). Most participants were prosecutors from a variety of ranks and locations across the three countries.

A major challenge in most comparative legal studies is to ensure comparability of the collected data, legal processes and procedures [25]. Comparative research inhibits the risk of misunderstandings [26, 27]. To minimise these risks and ensure comparability, we complemented the interviews with vignettes. Vignettes are relatively well established as a means of exploring how various factors influence decision making, particularly in the context of sentencing decisions [28] or regarding a breach of process during the pre-trial, sentencing or release phase [25]. Applications of the method generally tend to be quantitative in nature [29-31], but in recent years more qualitative approaches were implemented as well [25, 28, 32]. Vignettes make it possible to include contextual factors related to different jurisdictions in the scope of research,

\footnotetext{
${ }^{3}$ In the case of Germany data was provided by the Ministry of Justice of NRW.

${ }^{4}$ These focus groups took place in 2018 and 2019 during training sessions that were organised at the Academy of European Law (ERA) in Trier (Germany) as part of the aforementioned CrossBes-project.
} 
and to examine how these contextual factors - such as the culture-specific idiosyncrasies of different systems - may impact decision making [25].

The vignettes used during interviews consisted of brief case scenarios related to cross-border cooperation, with a focus on the transfer of judgements and prisoners. The scenarios included specific problems related to prisoner transfers, such as the question of how to determine the actual place of residence of a person, or of how to calculate the remaining prison term. The vignettes were accompanied by questions asking participants to respond to the scenario, either by giving their opinion regarding the course of action that should be taken, or by explaining what they would do in the situation presented [33]. A main challenge encountered while using this methodology was, on the one hand, to find a balance between adjusting the scenarios to the great array of procedures and processes within the different jurisdictions and, to ensure comparability of the collected data on the other. In short, finding a common scenario that makes sense and also respects jurisdictional differences is crucial and requires considerable time for preparation and pre-testing.

During focus group discussions, the vignettes were not used for practical reasons. Instead, open questions pertaining to the main challenges related to the daily practice of cross-border cooperation were asked and discussed. These discussions were not limited to topics concerning the three case countries, but also included information on legal cooperation with other (EU) countries.

Nevertheless, a number of methodological limitations related to this study must be taken into account; the qualitative part focuses on the procedures and practices with regard to transfers, which - in all three countries - falls mainly within the responsibility of the prosecution offices (either centralised or decentralised). Hence, only legal professionals with a prosecutorial background were interviewed, leaving other relevant legal practitioners - such as judges and lawyers - out of the picture. The limited number of interview partners is explained by the fact that transfer practices still remain a relatively unexplored branch of legal cooperation, and only few experts with sufficient experience in this area exist in the three countries.

\section{Rationale and practice of transferring Judgements and sentences}

Over the past decades, several instruments have been used for the transfer of sentenced persons within Europe. The Council of Europe was the main forum for the establishment of mutual agreements on prisoner transfers between its Member States, and drafted numerous legal instruments, such as the European Convention on the Supervision of Conditionally Sentenced or Conditionally Released Offenders (1964), the European Convention on the International Validity of Criminal Judgments (1970) and the Convention on the Transfer of Sentenced Persons (1983). The latter was ratified by 61 countries, including all Member States of the European Union, as well as Non-Member States, such as Canada and the United States ([23]: 112). Parallel to this convention, the EU Member States ratified the Agreement on the Application between the Member States of the European Communities of the Council of Europe Convention on the Transfer of Sentenced Persons (1987). This Agreement equates the rights of 'persons who have a permanent residence in a country' with those of nationals of that country, in line with the the application of the COE Convention of 1983. 
In 2008, based on an initiative by Austria, Finland and Sweden, FD 2008/909 and FD 2008/947 were established. FD 2008/909 replaced the old system of prisoner transfers and introduced some major innovations, such as the abolition of the consent requirement of the sentenced person and the principle of mutual recognition. Pursuant to its art. 29 (1), FD 2008/909 should have been implemented by 5 December 2011, but only five Member States had transposed it into national legislation by that date [20]. In the Netherlands and Belgium, FD 2008/909 came into force in 2012, while Germany was not able to implement it until 2015. FD 2008/947 was due to be implemented by 6 December 2011; the Netherlands did so in 2012, Belgium in 2013 and Germany in 2015.

FD 2008/909 and FD 2008/947 belong to the same 'family' of criminal justice framework decisions. While FD 2008/909 was designed to establish a system for the transfer of prisoners to the EU Member State of the person's nationality or habitual residence, or to the state with which they have close ties. FD 2008/947 effectively does the same with probation decisions and alternative sanctions (although the notion of the 'transfer' of a judgment is misleading as the decision is based on mutual recognition). Both FDs essentially have in common that a sentence is issued by one Member State and executed by another. Both place the social rehabilitation of the sentenced person at the very core of their rationale, assuming that reintegration is best achieved where social, family and professional ties exist.

There are, however, a number of significant differences in the implementation of the procedural provisions between FDs 2008/909 and 2008/947. FD 2008/909 does not require the sentenced person to consent to their transfer ([34]:6). Argumentum $e$ contrario, this means that a prisoner can be transferred to their country of origin or habitual residence even against their expressed will. This is not the case with regard to FD 2008/947: the probation decision or alternative sanction can be executed in any other Member State than the sentencing state, as long as the sentenced person has consented. In cases where the sentenced person has returned to the executing state, this consent is implied [34]. According to the European Commission, the reason that FD 2008/947 does require consent is that the FD only becomes operative if the person has already been released in the issuing state, and wants to return as free person to their home country, and is willing cooperate with the supervising authorities ([16]: 8). Both FDs are designed to reduce the number of imprisoned non-residential EU citizens; FD 2008/909 directly, and FD 2008/947 more indirectly - thereby reducing prison overcrowding and improving detention conditions ([16]: 12). FD 2008/909 operates in a straightforward manner by transferring prisoners to their country of origin or habitual residence. FD $2008 / 947$, on the other hand, is more subtle: it provides an easy way to execute probation measures and alternative sanctions in other Member States, and is supposed to provide an incentive for judges to treat non-nationals as nationals, and therefore make them more inclined to use custody only as a last resort ([17]: 357). According to the European Commission [16], the FD has the potential to lead to a reduction in prison sentences imposed on non-residential EU citizens, and foster their social rehabilitation. However, if this is the case, it is subject to controversial discussions.

\section{Social rehabilitation versus transfer of Judgements and prisoners?}

Social rehabilitation and reintegration (in this context both terms are used interchangeably) have been empirically and theoretically well-researched topics in the field of 
penology since the 70s [23]. Crime prevention, the reduction of recidivism, but also individual well-being are the primary goals of social rehabilitation. Interventions are best made within communities, and the length of the treatment must be adapted to the needs of the offender [35]. Finally, having a partner and family relationships, as well as being in employment reduce criminal behaviour [36]. Social rehabilitation, however, remains one of the biggest challenges facing penal practice. This holds particularly true for foreign prisoners; they experience numerous problems in prisons relating to culture, communication, access to services (such as work, medical and legal services), and contact with their families. Transferring prisoners to their countries of residence appears to be an effective solution to these specific problems [37].

Nevertheless, some authors have pointed to elements of the framework decisions that might actually be counterproductive - or even undermine - this goal of rehabilitation $[20,23,24]$. Although the ratio legis of both framework decisions is to promote social rehabilitation, no explanation is provided as to what this actually entails. It can be assumed that this has led to different interpretations of what 'social rehabilitation' entails and how it can be accomplished - depending on the national laws of the Member States. The same vagueness applies to the type of assessment that the issuing authorities are supposed to undertake ([19]: 50). FD 2008/909 (recital 9) determines that 'the competent authority of the issuing State should take into account such elements as, for example, the person's attachment to the executing State, whether he or she considers it the place of family, linguistic, cultural, social or economic and other links to the executing State.' But these links alone are not sufficient to reduce the probability of reoffending and might even encourage anti-social behaviour [38, 39].

Moreover, feedback and control mechanisms are unable to (properly) assess whether the purpose of social rehabilitation is actually fulfilled by transferring the prisoner. According to one of our interview partners, once the prisoner is 'out of sight', the case file is closed in the issuing state and further inquiries remain an exception. Any concerns that an executing state may have about whether a transfer serves the purpose of social rehabilitation - or whether it is actually counterproductive - can be voiced during consultations. Such concerns, however, do not constitute grounds for refusal (recital 10). Solely the issuing state may decide to withdraw the certificate if they are convinced that the purpose of social rehabilitation is not fulfilled ([20], 380).

There is a high probability that the goal of social rehabilitation will be undermined if a prisoner is transferred without his consent. There is not much doubt that measures taken against the expressed will of a prisoner, especially in the case of measures as significant as a transfer to another country, may negatively impact the prospects for reintegration into society. This, however, also works the other way around; a prisoner may voice their interest in being transferred to their country of residence, but authorities are not obliged to act upon their request. Authorities may decide to object to a transfer for any given reason, and execute the prison sentence within their own facilities. According to one of our interviewees, a common reason for such a rejection is that the penal system of the executing state is perceived as being too lenient, for example because the rules for early release are considered too generous. During the focus groups, concerns were voiced by some German and Dutch prosecutors regarding the Belgian practice of mainly using electronic monitoring on persons sentenced to less than 3 years in prison (see below). By rejecting a transfer, a harsher sentence may be ensured. This, however, would make sentences for foreign prisoners more repressive 
and would be inconsistent with the aims of rehabilitation that call for prescribing the least severe sanction ([23]: 119). Hence, the question of whether prisoner transfers undermine the goals of rehabilitation and correction, or whether they are in line with these ideals remains crucial.

\section{Empirical Data on the Implementation of Framework Decision 2008/909 and Framework Decision 2008/947.}

In contrast to the data on the EAW, which is centrally collected and published by the EU Commission, (empirical) data on the number of prisoner or judgement transfers pursuant to FDs 2008/909 and 2008/947 is scarce. Within the three case countries, regulations and practices regarding data collection in relation to both framework decisions vary. While the Dutch system for the transfer of both judgements and prisoners is centralised, and data is centrally collected and published [40], this is the case neither in Belgium nor in Germany. In Belgium, data on prisoner transfers are collected by the Ministry of Justice, while the transfer of judgements are handled by local prosecutors who do not report their casework to the central authorities. In Germany, the Bundesamt für Justiz (Federal Agency of Justice subordinated to the Federal Ministry of Justice) publishes annual statistics on extradition cases, which include prisoner transfers - but without distinguishing between them. Due to the federal system, statistics on the transfer of judgments and prisoners are collected by each state individually, with no obligation whatsoever to publish or report these to the Federal Ministry of Justice - as revealed in a recent parliamentary inquiry (Bundestag 2018). For this study, however, available data on prisoner transfers (Annex 1) were analysed including data on demographics of prison populations obtained from the Council of Europe SPACE 1 Report [41].

\section{The Netherlands}

The Netherlands has significantly reduced the number of prisoners over the past years, experiencing what can be called a reversed punitive turn, a unique development compared to other EU countries [42]. In 2016, a total of 8726 inmates were registered in Dutch prisons, resulting in an incarceration rate of 51.4 per 100,000 inhabitants, one of the lowest rates in the EU. The resulting empty prison space was temporarily rented out to Belgium and Norway, but both contracts ended in 2017. This drop in incarceration rates is due to a variety of factors, such as a drop in serious crimes, the increased use of community penalties, and the introduction of a 'master plan' by the Dutch government aimed at promoting a process of de-carceration [42, 43]. This trend towards a decrease, however, did not apply to all prisoners and did not include 'dangerous populations', such as irregular migrants and youngsters from ethnic minorities [44].

Concerning the question of prison transfers, the data on incarcerated non-Dutch EU citizens is of high interest. According to the Council of Europe, the number of foreign nationals in Dutch prisons amounted to $18.2 \%$ of the total prison population in 2016, including pre-trial detainees. Of all foreign prisoners including pre-trial detainees, 653 EU citizens were registered, or $7.5 \%$ of the entire prison population ([41]: 71). In terms of prisoner transfers, pursuant to FD 2008/909, the Netherlands is an import or 
receiving nation. According to data published by the Research and Documentation Centre (WODC) of the Ministry of Justice and Security ([40]: 42), since the implementation of FD 2008/909 in 2012, a total of 1155 certificates initiating a transfer to the Netherlands from another EU Member States were received by the Dutch authorities, namely the IOS (Internationale Overdracht Strafvonnissen) in The Hague. Since not every certificate received leads to a transfer, this resulted in the transfer of 586 prisoners to Dutch prisons, a ratio of approx. 51\%. During the same time period, only 118 outgoing certificates from the Netherlands to other EU Member States were registered, resulting in 22 executed transfers before the end of 2017. The ratio of outgoing to incoming certificates is approx. 1:10. Since 2012, most of the incoming certificates to the Netherlands were received from Belgium $(N=305)$, Germany $(N=304)$, and Great Britain $(N=128)$. Outgoing certificates from the Netherlands were mostly sent to Belgium $(N=11)$, Germany $(N=6)$, France $(N=3)$ and Poland $(\mathrm{N}=3)$.

While in the past Dutch authorities were rather reluctant to initiate prisoner transfers pursuant to FD 2008/909, the number of transfers pursuant to FD 2008/947 was somewhat higher. The transfer of judgements and probation decisions are dealt with centrally at the Internationale Rechtshulp Centrum (IRC) in the province of NoordHolland (Internationale Center for Legal Assistance). In the 2 years following the implementation of FD 2008/947 in 2016, a total of 137 judgments and probation decisions 'travelled' from the Netherlands to another EU Member State ([40]: 63). Most judgments were sent to Belgium $(N=86)$, followed by Poland $(N=21)$, and Germany $(N=16)$. During the same 2 years, only 44 cases were registered in which sanctions or probation measures - imposed by authorities of another EU Member State - were transferred to the Netherlands for execution. Out of all certificates received, 31 were executed by the Netherlands (execution rate of 74\%). The main sanctions of the incoming judgments were special sanctions (bijzondere voorwaarden) and community service (taakstraf). Most outgoing cases involved soft drug offences and abuse, for which community services were generally imposed.

Most noteworthy in relation to the Dutch transfer systems is the discrepancy between the number of certificates pursuant to FD2008/909 sent since $2012(n=122)$ and the actual number of transfers $(n=22)$. The reasons for the fact that less than $20 \%$ of all initiated transfers were actually carried out are manifold, as one of our interview partners conceded. To date, the lack of manpower has been a hindrance in that matter. In what concerns prison overcapacities, a lack of necessity might also have played a role. On the other hand, the number of outgoing transfers pursuant to FD 2008/947 was relatively high compared to that in NRW.

\section{Germany/NRW}

The prison population in Germany has been decreasing significantly over the past decade. Dünkel [45] even refers to Germany (and the Netherlands) as now belonging to the group of countries that in the past were characterised as 'exceptionalist'. The concept, which was originally used with reference to Nordic countries, describes a penal philosophy with a profound emphasis on normalisation and rehabilitation, with prisoners remaining part of the society to which they will return [46, 47]. The reason for the decline in the German prison population (over $22 \%$ since 2003) remains somewhat 
unclear, but is generally attributed to procedural law reforms and a decline in violent and sexual offences [45].

The total prison population in Germany amounted to 64,223 inmates in 2017, including pre-trial detainees ([48]: 5). According to the Council of Europe, in 2016, the prison population rate remained at 78.4 per 100,000 inhabitants, a relatively low rate compared to other EU countries ([41]: 37). Statistics on prisoner demographics vary depending on the data collection method and the state. According to the German government, the number of EU citizens in German prisons in March 2017 amounted to approx. $10 \%$ of all inmates $(N=5333)$, with the principle nationalities being Polish $(N=1325)$, Romanian $(N=1114)$, and Italian $(N=527)$ [48].

In Germany, prisons are 'Ländersache', meaning that the penal system falls within the responsibility of the states (Bundesländer). Since NRW is the only state that shares a border with both Belgium and the Netherlands, the focus of our research is on this Bundesland. For NRW, the most populated Bundesland in Germany, the prison statistics show that the number of inmates amounted to 15,862 in March 2017, distributed across 37 of the 183 German prisons [49]. This makes up for nearly one fourth or 24,4\% of all German prisoners. Since official data on prisoners' demographics were not available, the rate of foreign EU nationals in NRW prisons can only be estimated by applying the average of $10 \%$, in this case amounting to approx. 1500 inmates. This, however, is a conservative estimation, as the proximity of NRW to the Dutch and Belgian borders, and the relatively high rate of (EU) migrants among its resident population, may have had an impact on the ratio of EU inmates in prisons.

With regard to the transfer of judgements and prisoners, it needs to be taken into consideration that FD 2008/909 and FD 2008/947 were adopted by Germany with a delay and entered into force only in July 2015. Consequently, no data are available for the previous years. In 2016, prisoner transfers pursuant to FD 2008/909 resulted in 61 transfer cases from NRW to another EU country. Of those prisoners, 55 were transferred to the Netherlands and one to Belgium. In 2017, this number increased slightly to 72 prisoners being transferred from NRW to another EU country, of whom 52 were transferred to the Netherlands and three to Belgium. On the following ranks for both years, were Italy $(N=5)$, Poland $(N=4)$ and France $(N=3)$ (the aggregated numbers are shown in Annex 1, Table 2).

As for transfers pursuant to FD 2008/947, the caseload in NRW has been significantly lower. According to the Ministry of Justice NRW, the number of incoming requests from other EU countries to take over probation measures and alternative sanctions amounted to 19 cases between January 2015 and May 2018. Approximately two-thirds of all requests were issued by the Netherlands. Surprisingly, the number of outgoing cases, meaning the instances where NRW requested another EU country to take over a probation measure or alternative sanction, amounted to just one case by the end of 2017 (Annex 1, Table 2). When asked about this exceptionally low caseload, an interview partner from Germany noted that this was probably due to the relatively short period of time since the implementation of FD 2008/947. However, legal practices may also influence this low input/output ratio. Judges and prosecutors seem rather reluctant to engage in the relatively complex and bureaucratic process of a judgment transfer, particularly for measures that are commonly perceived as lenient and serving more as a warning, rather than a punishment. 


\section{Belgium}

According to the official prisoner statistics collected by the Council of Europe, Belgium counted 11,615 prisoners in 2016 (including pre-trial detainees), of which 4726 (approx. 41\%) were non-Belgian nationals ([41]:71). More than 130 different nationalities were represented among inmates in Belgian prisons, the largest group consisting of Moroccans, followed by Algerians [50]. According to the Belgian Ministry of Justice, the total number of EU citizens (including pre-trial detainees) amounted to 628 prisoners by the end of 2017. Assuming that the prison population had not changed significantly throughout 2017 , this number would have made up for about $5 \%$ of the entire prison population (including pre-trial detainees). In terms of prisoner demographics, the largest groups of EU nationals were Romanians $(N=126)$, followed by Dutch $(N=111)$ and French $(N=98)$. With 10 inmates, Germans made up for one of the smallest groups [50].

Due to frequent strikes of prison personnel in the past years, the Belgian prison system came under criticism for its high incarceration rate, overcrowding and harsh prison conditions [51]. Due to an increase of people in pre-trial detention and long prison sentences since the 1990s, the detention rate in Belgium increased from 65 per 100,000 inhabitants in the 1980 s, to 95 per 100,000 in 2005 [52]. In 2016, this rate had further increased to 102.7, exceeding prison capacities significantly [41]. One strategy to relieve the problem of overcrowding is the increased use of electronic monitoring, making it possible for convicted persons to serve their prison sentence in their community under limited supervision $[53,54]$. According to one interviewed Belgian expert, it is a widespread practice in Belgium to monitor persons with sentences of less than 3 years via electronic surveillance rather than detaining them.

In relation to the transfer of prisoners pursuant to FD 2008/909, the case numbers have risen continuously since the framework decision came into force in 2012. Between 2013 and the end of 2017, the Belgian Ministry of Justice registered 169 cases of outgoing transfers to other EU Member States (Annex 1, Table 1). The three main transfer countries since 2013 have been the Netherlands $(N=77)$, France $(N=38)$ and Romania $(N=30)$. Data on incoming certificates and transfers were not available. The same applies to data on transfers pursuant to FD 2008/947, which is not centrally collected by the Ministry of Justice.

\section{Interpretation of the case data}

The relatively small number of transfers, the differences between the various penal and prison systems, and the partly incomplete data make a comparative assessment of the transfer system complicated. In addition, different prisoner demographics, as well as the different sizes of prisoner populations, have to be taken into account when assessing the transfer system and interpreting the case data. However, it can be concluded that prisoner transfers in all three case countries play a relatively small role compared to the total number of foreign EU prison inmates that are theoretically (meaning based only on nationality) eligible for transfers. In other words: while the number of imprisoned EU foreigners in all three case countries is relatively high, the number of inmates who actually get transferred to their countries of nationality is rather low. In 2017, for example, the number of transferred EU inmates from Belgian prisons amounted to 
approx. $8 \%$ of the total number of incarcerated EU nationals. In NRW, this number is estimated at about $5 \%$ of all EU inmates, while in the Netherlands, transferred prisoners only made up for $1 \%$ of EU prisoners. However, this interpretation is limited in the sense that no accurate predication can be made regarding the number of EU prisoners who were indeed eligible for a transfer, meaning that they had their habitual residence, family and social ties etc. in another EU Member state.

Moreover, the data concerning the receiving countries gives some indication as to whether prisoner transfers have been used for the purpose of migration control. Concerns regarding the potential use of transfers for deportation purposes were voiced soon after the adoption of FD 2008/909 in 2008 [19, 23, 24]. Pakes and Holt [55] speak of a 'quite possibly disturbing trend', which begs the question if 'prisoners are farmed out to serve their sentence in foreign countries, not because of prisoners' individual circumstances but due to national governmental policymaking.' Bosworth et al. [56] see 'postcolonial and neo-colonial dynamics' at work, given the growing number of intra-EU transfers. Some scholars suspect a 'hidden agenda' behind transfers, namely to get rid of criminal migrants, with the welcome side-effect of reducing prison overcrowding [20]. These concerns could be integrated in the wider scientific debate on 'crimmigration'; this term - originally coined in the US - has become a central criminological concept that focuses on the growing merger of crime control and immigration control $([42,57,58])$. Criminologists describe this phenomenon as a shift of immigration laws towards criminal law measures, and a transformation of criminal justice practices in which measures and practices related to immigration law are used against those within the criminal justice system, mostly non-citizens [42]. These dynamics are believed to result in harsher punishments for foreign prisoners; a group which is more likely to be imprisoned on remand while awaiting trial and sentencing, given the longer custodial sentences, refused re-categorisation to more open prison conditions, and ultimately, deportation after having served their sentence [59-62].

These crimmigration dynamics have been described for Belgium, the Netherlands and Germany as well, three countries whose prison populations are to a considerable extent composed of EU and other foreign nationals. However, empirical research on crimmigration dynamics has been scarce so far [57]. In light of this debate, the collected data on prisoner transfers allow for some interpretations and cautious conclusions. Table 2 (Annex 1), showing outgoing prisoner transfers categorised by receiving country, demonstrates that in all three case countries, the neighbouring countries are the preferred destinations for prisoner transfers. As much as $80 \%$ of all transferred prisoners from NRW $(N=107)$ went to the Netherlands, the second largest group consisting of transfers to Belgium with five cases. Belgium transferred 77 prisoners or approx. $45 \%$ of all transfers - to the Netherlands, while $22 \%$ were transferred to France, the western neighbour (none, however, to Germany). When taking certificates into account, Dutch authorities sent - between 2013 and 2017 - the majority of transferred prisoners to Belgium $(N=36$ or $31 \%)$, Germany $(N=17$ or $14 \%)$ and France $(N=15$ or $13 \%)$ ([40]: 53). In fact, in all three case countries, either the most or the second most transfers were conducted with a neighbouring country.

Hence, the amount of transfers from the three case countries to other EU Member States where migration control purposes play a relevant role (i.e. Eastern and Southeastern Europe) is considerably lower. For example, Romanians, a migrant group 
frequently subjected to deportation measures [63], make up for the second largest group in German prisons in the years 2016 and 2017 [64]. However, only three inmates were transferred from NRW to Romania since 2016. From Belgium, where Romanians also represent the largest group of foreign inmates, 30 transfers were conducted to Romania between 2013 and 2017. One reason for this might be the fact that transfers and extraditions to Romania were reduced - or even halted entirely - by some Member States, due to the notoriously bad prison conditions in the country. When taking into account countries in the wider region of Eastern Europe, this picture remains the same: of the total number of Polish prisoners (traditionally representing one of the largest national groups in German prisons), only five inmates were transferred to Poland since 2016. Only three prisoner transfers were conducted to Bulgaria from Belgium since 2013, and not a single one from NRW since 2016. Between 2013 and 2017, out of the 118 outgoing certificates from the Netherlands, only 12 sentenced persons (approx. $10 \%$ ) were sent to Bulgaria, Hungary, Croatia and Romania - and not even all these certificates resulted in an actual transfer ([40]: 53).

The empirical data shows that most transfers from NRW, Belgium and the Netherlands are conducted between neighbouring countries, where formal and informal networks of legal cooperation are traditionally strong. It seems that migration control purposes, at least with regard to EU citizens, have played a minor role so far. This interpretation is not limited to the relation between the three case countries, but also applies to south and southeastern Member States - whose citizens are specifically vulnerable to migration control measures.

However, it needs to be considered that due to the limited data and small number of cases, our interpretations cannot simply be generalised to other EU Member States or the entire EU. It might therefore be the case that other Member States do instrumentalise the transfer systems to systematically get rid of unwanted migrants, or to relief their overcrowded prisons. But for the Netherlands, Belgium and NRW, the total number of transfer cases is simply too low to speak of a systematic exploitation of the transfer system. This, of course, is not to say that the situation may change not in the near future.

\section{Challenges for the Implementation of Framework Decision 2008/909 and Framework Decision 2008/947.}

As the quantitaive data on transfer cases alone has limited informative value, this study includes a qualitative dimension as well. Interviews with legal experts help to gain a clearer understanding of how the penal transfer system influences - and is influenced by - cross-border legal cooperation. The aim was to gain deeper insight into the underlying motives for initiating transfers, the rationales that shape them, and the way they are implemented in daily legal practice. Nearly all our interviewed experts from the three case countries conceded that there was room for improvement in relation to the total number of transfers. Yet, frictions created by the different legal and penal systems of the EU Member States slow down cooperative processes. This lack of compatibility is a challenge, also in the three case countries. But legal issues represent only one side of the coin, the very practical dimension of daily cooperation being the other. It has been well established that in cross-border cooperation in criminal investigations, informal networks and practices play a significant role [3]. The same applies 
to legal cooperation in sentencing. The three main issues identified in all three countries were the problem of adapting sentences, the assessment of habitual residence, and the question of consent.

\section{The adaption of sentences}

A crucial aspect related to issuing a certificate is the calculation of the (remaining) sentence. Often the cumulation and calculation of the prisontime pose significant problems for the executing state. This is, for example, the case for calculating the number of days to be spent in prison, especially when it concerns more than one prison sentence, or when the days spent in pre-trial detention have to be subtracted. Besides the lack of information in certain instances, the basis of calculation itself is sometimes an issue. As one of our interview partners from Belgium mentioned, the simple difference between calculating months (each with 30 days) or years (with 365 days) can lead to discrepancies in the final prison term. But every day spent in prison unjustified is a serious violation of the prisoner's rights, and not a trivial or tolerable issue. Despite the principle of mutual recognition limiting the discretion of the executing state to simply adapt the sentence to its own national system, a streamlining of procedures in the Member States is urgently required.

Closely related are difficulties arising from the different legal systems and, in relation to FD 2008/947, from the adaption of alternative sanctions. The socalled taakstraf - or community service - is widely used in the Netherlands, but poses a problem when transferred to Germany. The German penal system recognises (for adults) custodial sentences and financial penalties, while community service is a conditional sentence, meaning that it cannot be executed independently from the main sentence. Since community service has become a very common form of sentencing in the Netherlands, recognition issues arise for German authorities in case of transfers. In practice, the community service is often converted into a monetary fine, depending on the duration of the community sentence. But problems remain, as the basis for calculating the fine is unclear, and standardized solutions, for example for cases where the sentence is revoked, are still lacking. This bears the risk of a reformatio in peius, for example, where the taakstraf is converted into a prison sentence. Several of our interview partners considered it as one of the main challenges for the future to establish guidelines to adjust and convert alternative sanctions into equivalent measures within the different penal systems.

\section{The assessment of 'Where a Person Lives'}

A crucial issue for the transfer under FD 2008/909 and FD 2008/947 is the question of where the convicted person lives. In contrast to FD 2008/947, which only refers to a 'lawful ordinary residence', the term 'lives' - in FD 2008/909 recital 17 - refers to the place to which the person 'is attached, based on habitual residence and on elements such as family, social or professional ties'. This notion of 'living' is based on the presumption that prisoners have better chances of reintegration where social ties are strong. This, however, has sparked some debate and so has the rather imprecise 
criterium of 'habitual residence' ([19]: 56; $[18,65])$. Since clear guidance and case law is lacking in this area, a case-by-case evaluation on where a person lives or has their habitual residence becomes necessary.

In the Netherlands, the question of whether the convicted person has a demonstrable and sufficient connection to the Netherlands, and whether the transfer will contribute to the resocialisation chances of the convicted person, influences the transfer decision significantly. Different criteria, such as the habitual place of residence, the period the sentenced person has lived there, the workplace, as well as the place of residence of the family, are assessed. In addition, questions regarding economic ties and the possibility of setting up a resocialisation programme during the execution of the custodial sentence may play a role [66].

Ideally, transfer procedures manage to find a balance between the need for effective enforcement of sentences across borders and the aim of social rehabilitation. Martufi [19] especially criticises that consultations between the issuing and executing state on the question of habitual residence often take place only after the sentence has been forwarded, and a decision on the transfer has already been made. He recommends scheduling this consultation before the transfer and, in addition, acquire information about the prisoner's social background by interviewing the prisoner's family and requesting a pre/post-sentence report by the executing state's prison and/or probation service. Moreover, a substantiated motivation for the transfer should be provided by the competent authority, and a mandatory judicial hearing of the prisoner should take place. It is worth noting that FD 2008/909 does not specify an appeal procedure against a transfer decision. It does, however, mention in recital 22 that "a final decision including an appeal procedure is completed within a period of 90 days", thereby leaving it to the legislators in the Member States to provide legal remedies. Germany, for example, has incorporated an appeal procedure in Section $85 \mathrm{~b}$ of the Act on International Cooperation in Criminal Matters (IRG). The gathering and exchange of relevant information concerning the habitual residence, family, professional and social ties is one of the most complex aspects of the transfer procedure, and left at the discretion of the issuing member state. It might therefore come as no surprise that the assessment of habitual residence are conducted quite differently in the three countries. Whereas in the Netherlands and Belgium the immigration offices are involved as a provider of information on the offender, this is to a lesser extent the case in Germany, where the official resident register is a main source of information. This register, however, has been proven to not always be reliable. Therefore, in addition to the register, the habitual residence is mainly determined based on self-reporting of the convicted person in the initial stage of their sentencing hearing. If, however, the prosecution deems it necessary, it can request more data on the actual place of residence from other authorities. But it remains unclear as to whether and, if so, how often this occurs. Given the complexity of determining the place of actual residence, our data suggest that self-reporting of the sentenced person remains a crucial criterium, although authorities increasingly attempt to base their decisions on more objective information. 


\section{The question of consent}

In FD 2008/947, the issue of the sentenced person's consent to a transfer is rather avoided ([21]: 362). This, however, is not the case in FD 2008/909, where Article 6 clearly sets out the circumstances under which this consent is not required, stating three criteria:

- the person is a national of the country of the executing state and also lives there;

- the person would be deported to the executing state on completion of their sentence; or,

- the person has fled or otherwise returned there [the executing state] in response to the criminal proceedings.

A significant number of imprisoned foreign EU nationals meet one of these criteria. Hence, in a report by Europris, several Member States conceded that a high proportion of transfers were made without the affected individual having provided consent (see [67]: 45). However, our research found no indications that these practices also play a role in transfer procedures in the Netherlands, Germany and Belgium. It must be taken into consideration that consent, even if not expressed explicitly, may be considered in different ways, such as the possibility for the sentenced person to initiate a transfer, the right to be heard, and the right to veto a transfer ([23]: 118). Hence, in the three case countries, procedures regarding the assessment of consent differ from each other. In the Netherlands and Belgium, a transfer procedure is often proactively initiated by the authorities. A form is used where the convicted person can voice their concerns regarding their potential transfer. Among German prosecutors, it even seems customary that if a prisoner does not proactively request a transfer, prosecution offices remain inactive. One of our German interviewed experts, a prosecutor dealing specifically with cross-border cooperation issues with the Netherlands, stated that only the transfer request of the prisoner themselves is considered a starting point to assess whether further steps can be taken. Even if the prisoner proactively requests a transfer before the formal procedure is initiated, a hearing before a judge is required.

Indeed, the criteria for consent, require informing the prisoner of the possible consequences of a transfer to their country of origin. An informed decision implies having access to viable information regarding, inter alia, the terms for conditional release, access to prison benefits, other rights (e.g. visits, leave, correspondence, intimate visits), access to work, and the length of the transfer procedure itself [38]. A recent study by Durnescu et al. [21] among Romanian prisoners in Spain and Italy showed that the so-called 'release effect' is an important factor for prisoners to consider a transfer. According to their study, a transfer procedure is viewed as beneficial when it contributes to a reduction in the prison term, therefore making the conditions for an early release a crucial motivating factor for a transfer. One of our interviewees from Belgium corroborated this fact by stating that mainly Romanian, but also Dutch and French prisoners in Belgium, tend to proactively request a transfer to their countries of origin, as early release conditions are perceived as being more favourable in 
these Member States. Surprisingly, Durnescu et al. found that the length of time required for the transfer procedure, and the uncertainty of the outcome, seem to have a demotivating effect on prisoners, although one could assume that the notion of time and patience play a lesser role in prison ([21]: 461).

Despite the legal practices in terms of the consent requirement Graat et al. [66] point to the fact that there are no safeguards in Dutch legislation to ensure that the convicted person's consent for a transfer was obtained. The same holds true for the provision of information by the prosecutor on the possibility of a transfer and details concerning the procedure, as well as prison conditions in the executing state. In practice, the provision of accurate information on the legal and penal systems of other Member States remains difficult due to the variety of systems and conditions of imprisonment, which, moreover, are subject to change over time.

Concerning the question of how deportation regulations may influence the assessment process, the following example from Germany is noteworthy: one of our German interviewed experts pointed to $\S 456 \mathrm{a}$ of the German Criminal Procedural Code (Strafprozessordnung), which, in his opinion, is a crucial factor affecting the willingness of EU foreigners to consent to a transfer. This law provides authorities with the possibility to deport non-national prisoners after having served only half of their sentence (usually two-thirds of a prison sentence is to be served in Germany). However, early release can only take effect on the condition that the sentenced person leaves Germany upon release, and will not re-enter the country. Similar regulations exist in a number of EU countries, including Belgium and the Netherlands, and are often criticised for subjecting foreign prisoners to the combined force of a prison sentence and (the threat of) deportation [42]. Our interview partner, however, suspected that it was the aforementioned criminal procedural rule - and the prospect of being released (exceptionally) early - that leads to foreign prisoners preferring a prison stay in Germany and refraining from proactively initiating a transfer, despite the consequential expulsion. Here again, it is not the threat of deportation, but rather the early-release effect that might play a role in transferring to a system with supposedly longer prison stays the less favourable choice.

\section{Conclusion}

This study explored the European system for transferring sentenced persons to their countries of origin, exemplified by legal and cooperative practices between the Netherlands, Belgium and Germany. Based on empirical data regarding the transfer of prisoners, as well as the transfer of judgements and probation decisions, we found that to a large extent, these transfers took place between the three case countries, and to a much smaller extent with other EU Member States. This does not come as a surprise given the geographical, legal and cultural proximity of the three countries. After all, cross-border cooperation is an adhoc activity where formal structures based on contractual legal obligations sometimes evolve into informal cooperation networks based on behavioural norms - if perceived as reciprocal and advantageous [68]. Moreover, the empirical analysis indicates that despite the growing number of EU foreigners in 
Belgian, Dutch and German prisons, there is little evidence to suggest that a migration control agenda is controlling the transfer system. This conclusion is supported by the qualitative data: considerations concerning the actual place of residence, human rights issues, social rehabilitation and the consent of the sentenced person influence the transfer procedure substantially. In some instances, practitioners seem somewhat reluctant to initiate transfers, often leaving it up to the prisoners themselves to initiate the process. All these practices distinguish transfers from deportations, and contradict the suspicion of instrumentalising the transfer system for the purpose of migration control. This is also reflected in the overall very modest number of outgoing transfers from all three countries to countries in Southern and Eastern Europe respectively. The transfer of judgements and prisoners remains the exception, not the rule.

This, however, is not to say that an influence of migration control purposes on the transfer system can be fully denied or that in time, the practice of transferring sentenced persons will change. After all, the transfer system was only implemented in 2012 in the Netherlands and Belgium, and only in 2015 in Germany, so the system is still in an early development stage. It needs to be taken into account that our research focused only on imprisoned EU-foreigners in the three case countries over a relatively short period of time. This excludes a large number of prisoners with non-EU migration backgrounds eligible for prisoner transfers outside of the EU, as well as the growing number of inmates in deportation facilities. Generalised statements concerning the phenomenon of crimmigration, and the role of migration control dynamics within the EU penal systems, can therefore not be made.

Numerous challenges with regard to the transfer of prisoners still remain: some were discussed in depth as part of this study, others had to be left out due to the limited scope of this study. One issue that remains, for example, is the question of how to deal with sentences that include psychiatric or health care measures. According to Art. 9 of FD 2008/909, the executing state may refuse to recognise judgements containing such measures, which has meant that no such case has been reported to date. But how will Member States deal with this issue in the future? In fact, our research has shown that the prosecution services in all three case countries lack reliable information on available rehabilitation and psychiatric care programmes in other Member States. Probably, the same conclusion can be drawn in relation to other prison facilities, i.e. drug programmes, cell-configuration, prison regime, and so on. Another unresolved issue is the question of which role victim rights play within the realm of prisoner transfers.

In the bigger picture, the transfer system heavily relies on mutual trust and recognition, the cornerstones of judicial cooperation in criminal matters among EU Member States [69-71]. But reservations towards this principle still exist, resulting in a discrepancy between a legal and an empirical reality, where trust in other EU national legal systems is not felt and lived by the actors [66]. The reasons for this mistrust are manifold. For example, recent reports about deteriorating prison conditions in Belgium, issued by the European Committee for the Prevention of Torture and Inhuman or Degrading Treatment or Punishment [51], have led Dutch and German authorities to re-evaluate prisoner transfers to their neighbour. 
Besides this mistrust, we came across a certain degree of frustration among legal practitioners, which originates from a (perceived) incompatibility of sentencing systems within the EU. Asp [72] states that the 'Harmonization of sentencing should be looked upon as sort of a last-stage-harmonisation [...]'. ${ }^{5}$ But this harmonisation of national sentencing systems would require amendments to the EU treaties. Implementing a system for the transfer of sentenced persons prior to having a harmonised criminal law system in place, is 'putting the cart before the horse', apparently an increasingly common rationale of EU policies [73]. ${ }^{6}$ In order to create a smoothly running transfer system and overcome the issues of implementation, the Member States are 'nudged towards harmonisation'. ${ }^{7}$ Time will tell whether this strategy will be successful, and result in standardised criminal law and penal systems among all EU Member States. ${ }^{89}$

\section{Appendix 1}

Table 1 Outgoing and incoming prisoner transfers pursuant to FD 2008/909 from NL, BE and NRW to/from other EU Countries until 2017

\begin{tabular}{lllllll}
\hline & 2013 & 2014 & 2015 & 2016 & 2017 & total \\
\hline NL outgoing & 1 & 7 & 3 & 5 & 6 & 22 \\
NL incoming & & 35 & 56 & 80 & 207 & 208 \\
BE outgoing & 10 & 23 & 41 & 44 & 51 & 169 \\
BE incoming & & & & & & \\
NRW outgoing & & & 61 & 72 & 133 \\
NRW incoming & & & & 13 & 24 & 37 \\
\hline
\end{tabular}

\footnotetext{
${ }^{5}$ No data was available for incoming certificates and transfers to Belgium

${ }^{6}$ Since FD 2008/909 was adopted in 2015 by Germany no data was available for the years 2013-2015

${ }^{7}$ No data was available for Belgium concerning FD 2008/947.

${ }^{8}$ Case Data for NRW between 2015 and 2017.

${ }^{9}$ For illustrative reasons the included data reflects only certificates sent to other Member States and not the actual transfers conducted pursuant to FD 2008/909 (Number total transfers $n=22$ ).
} 
Table 2 Total outgoing transfers pursuant to FD 2008/909 and FD 2008/947 from NL, BE and NRW aggregated by EU Countries until 2017

\begin{tabular}{|c|c|c|c|c|c|}
\hline & $\begin{array}{l}\text { From BE FD } \\
2008 / 909\end{array}$ & $\begin{array}{l}\text { From NRW FD } \\
2008 / 909\end{array}$ & $\begin{array}{l}\text { From NL FD } \\
2008 / 909\end{array}$ & $\begin{array}{l}\text { From NRW FD } \\
2008 / 947\end{array}$ & $\begin{array}{l}\text { From NL FD } \\
2008 / 947\end{array}$ \\
\hline AT(Austria) & & 1 & & & \\
\hline BE (Belgium) & & 5 & 36 & & 86 \\
\hline BG (Bulgaria) & 3 & & 1 & & \\
\hline $\begin{array}{l}\text { CZ (Czech } \\
\text { Rep.) }\end{array}$ & & & & & 1 \\
\hline \multicolumn{6}{|l|}{ CY (Cyprus) } \\
\hline $\begin{array}{l}\text { DE } \\
\text { (Germany) }\end{array}$ & & & 17 & & 16 \\
\hline $\begin{array}{l}\text { DK } \\
\text { (Denmark) }\end{array}$ & & & 4 & & 1 \\
\hline \multicolumn{6}{|l|}{ EE (Estonia) } \\
\hline \multicolumn{6}{|l|}{ EL (Greece) } \\
\hline ES (Spain) & 3 & 2 & 5 & & 3 \\
\hline FI (Finland) & & 1 & 2 & & 1 \\
\hline FR (France) & 38 & 3 & 15 & & \\
\hline HR (Croatia) & & & 2 & & \\
\hline HU (Hungary) & 1 & & 5 & & 1 \\
\hline \multicolumn{6}{|l|}{ IE (Ireland) } \\
\hline IT (Italy) & 9 & 5 & 2 & & \\
\hline $\begin{array}{l}\text { LT } \\
\text { (Lithuania) }\end{array}$ & 2 & 1 & & & 1 \\
\hline \multicolumn{6}{|l|}{$\begin{array}{l}\text { LU } \\
\text { (Luxem- } \\
\text { bourg) }\end{array}$} \\
\hline \multicolumn{6}{|l|}{ LV (Latvia) } \\
\hline MT (Malta) & & & & & 1 \\
\hline $\begin{array}{l}\text { NL } \\
\text { (Nether- } \\
\text { lands) }\end{array}$ & 77 & 107 & & 1 & \\
\hline PL (Poland) & & 4 & 10 & & 21 \\
\hline PT (Portugal) & & & 4 & & 2 \\
\hline $\begin{array}{l}\text { RO } \\
\text { (Romania) }\end{array}$ & 30 & 3 & 4 & & 2 \\
\hline SE (Sweden) & & 1 & & & \\
\hline \multicolumn{6}{|l|}{ SI (Slovenia) } \\
\hline SK (Slovakia) & 3 & & 1 & & \\
\hline $\begin{array}{l}\text { UK (U. } \\
\text { Kingdom) }\end{array}$ & 3 & & 10 & & 1 \\
\hline Total & 169 & 133 & 118 & 1 & 137 \\
\hline
\end{tabular}


Open Access This article is licensed under a Creative Commons Attribution 4.0 International License, which permits use, sharing, adaptation, distribution and reproduction in any medium or format, as long as you give appropriate credit to the original author(s) and the source, provide a link to the Creative Commons licence, and indicate if changes were made. The images or other third party material in this article are included in the article's Creative Commons licence, unless indicated otherwise in a credit line to the material. If material is not included in the article's Creative Commons licence and your intended use is not permitted by statutory regulation or exceeds the permitted use, you will need to obtain permission directly from the copyright holder. To view a copy of this licence, visit http://creativecommons.org/licenses/by/4.0/.

\section{References}

1. Spapens, T. (2008). Policing a European border region. The case of the Meuse-Rhine Euroregion. In E. Guild, \& F. Geyer (Eds.), Security versus justice? Police and judicial cooperation in the European Union (pp. 225-242). Routledge.

2. Fijnaut, C. J., \& Spapens, A. C. (2005). Criminaliteit en rechtshandhaving in de Euregio Maas-Rijn. Deel 1. De problemen van transnationale (georganiseerde) criminaliteit en de grensoverschrijdende politiele, justitiele en bestuurlijke samenwerking. Antwerpen/Oxford: Intersentia.

3. Peters, M., Vanderhallen, M., \& Nelen, H. (2015). Cross-border criminal investigation in the MeuseRhine Euroregion: International policing and the theory of (inter-) Organisational conflict. European Journal on Criminal Policy and Research, 22(1), 41-60.

4. De Sousa, L. (2013). Understanding European Cross-border Cooperation: A Framework for Analysis. Journal of European Integration 35(6), 669-687.

5. Bruinsma, M. Y., Jacobs, M. G., Jans, M. W., Moors, J. A., Spapens, A. C., \& Fijnaut, C. (2010). Grensoverschrijdende dimensies van het politiewerk in de regio Limburg-Noord. Tilburg: IVA beleidsonderzoek en advies.

6. Knippenberg, H. (2004). The Maas-Rhine Euroregion: A Laboratory for European Integration? Geopolitics, 9(3), 608-626.

7. Nelen, H., Peters, M., \& Vanderhallen, M. (2013). Grensoverschrijdende Recherche in de Euregio Maas- Rijn.Knooppunten, knelpunten en kansen. Politie \& Wetenschap.

8. Van Daele, D., \& Vangeebergen, B. (2010). Kriminalität und Strafverfolgung in der Euregio MaasRhein. Antwerpen/Oxford: Intersentia.

9. Vermeulen, G. \& Van Damme, Y. (2010) Nederlandse afhandeling van Belgische rechtshulpverzoeken. IRCP-series, Vol 39. Maklu: Antwerpen.

10. Nelen, H. (2008). Evidence maze. Het doolhof van het evaluatieonderzoek. Maastricht: Maastricht University Press.

11. Van de Bunt, H. G. (2000). Aan het eind van de keten; de strafexecutie stiefmoederlijk bedeeld. Justitiële verkenningen, 4, 10-18.

12. Van der Heide, W., \& Eggen, A. (2007). Criminaliteit en rechtshandhaving 2006. WODC/CBS, Den Haag: Boom Juridische uitgevers.

13. Van de Bijl, O. (2012). Duizenden criminelen ontlopen jaarlijks Hun straf, Algemeen Dagblad, 24 Februar 2012.

14. Bewarder, M. (2016). Mehr als 107000 offene Haftbefehle in Deutschland. Welt, 21 April 2016. Retrieve from https:/www.welt.de/politik/deutschland/article154612766/Mehr-als-107-000-offene-Haftbefehlein-Deutschland.html

15. Klimek, L. (2015). European arrest warrant. Springer.

16. European Commission (2014). Report From The Commission To The European Parliament And The Council on the implementation by the Member States of the Framework Decisions 2008/909/JHA, 2008/947/JHA and 2009/829/JHA on the mutual recognition of judicial decisions on custodial sentences or measures involving deprivation of liberty, on probation decisions and alternative sanctions and on supervision measures as an alternative to provisional detention. $\operatorname{COM}(2014) 57$ final.

17. Durnescu, I. (2017). Framework decisions 2008/947 and 2009/829: State of play and challenges. ERAForum, 18, 355-363.

18. Marguery, T., van den Brink, T., \& Simonato, M. (2018). Limitations on the obligation of mutual recognition and fundamental rights protection in the EAW, FD 2008/909 and FD 2008/947. In T. Marguery (Ed.), Mutual trust under pressure, the transferring of sentenced persons in the EU, transfer 
of judgments of conviction in the European Union and the respect for Individual's fundamental rights. Retrieved from https://euprisoners.eu/documents/

19. Martufi, A. (2018). Assessing the resilience of 'social rehabilitation' as a rationale for transfer: A commentary on the aims of framework decision 2008/909/JHA. New Journal of European Criminal Law, 9(1), 43-61.

20. Pleić, M. (2018). Challenges in cross-border transfer of prisoners: Eu framework and Croatian perspective. In D. Duić, T. Petrašević (Eds.), Eu law in context - Adjustment to membership and challenges of the enlargement - conference book of proceedings, EU and comparative law issues and challenges (pp.375-399). Publisher University Josip Juraj Strossmayer Of Osijek.

21. Durnescu, I., de Tudela, E., \& Ravagnani, L. (2017). Prisoner transfer and the importance of the 'release effect'. Criminology \& Criminal Justice, 17(4), 450-467.

22. Vermeulen, G., Van Kalmthout, A., Paterson, N., Verbeke, P., De Bondt, W. (2011) Cross-border execution of judgements involving deprivation of liberty in the EU overcoming legal and practical problems through flanking measures. IRCP-series volume 40. Maklu: Antwerpen.

23. De Wree, E., Vander Beken, T., \& Vermeulen, G. (2009). The transfer of sentenced persons in Europe. Punishment \& Society, 11(1), 111-128.

24. Vermeulen, G. (2007). Mutual Instrumentalization of criminal and migration law from an EU perspective. European Journal of Migration and Law, 9(3), 347-361.

25. Maguire, N., Beyens, K., \& Boone, M. (2015). Using vignette methodology to research the breach comparatively. European Journal of Probation, 7(3), 241-259.

26. Farrington, D. P. (2015). Cross-national comparative research on criminal careers, risk factors, crime and punishment. European Journal of Criminology, 12(4), 386-399.

27. Robinson, G., \& Svensson, K. (2015). Fish out of water? Introduction to the special issue on innovative methods for comparative research on offender supervision practice. European Journal of Probation, 7(3), $171-178$.

28. Davies, M., Takala, J. P., \& Tryer, J. (2004). Sentencing burglars and explaining the differences between jurisdictions: Implications for convergence. British Journal of Criminology, 44(1), 741-758.

29. Anderson, J. M., Kling, J. R., \& Stith, K. (1999). Measuring interjudge sentencing disparity: Before and after the federal sentencing guidelines. Journal of Law and Economics, 42(1), 271-308.

30. MacDonald, S., Erickson, P., \& Allen, B. (1999). Judicial attitudes in assault cases involving alcohol or other drugs. Journal of Criminal Justice, 27(3), 275-286.

31. Tufts, J., \& Roberts, J. V. (2002). Sentencing juvenile offenders: Comparing public preferences and judicial practices. Criminal Justice Policy Review, 13(1), 46-64.

32. Beyens, K. (2000). Straffen als sociale praktijk. Een penologisch onderzoek naar straftoemeting. Brussels: VUBPress.

33. Hughes, R. (1998). Considering the vignette technique and its application to a study of drug injecting and HIV risk and safer behavior. Sociology of Health \& Illness, 20(3), 381-400.

34. European Commission (2011). Strengthening mutual trust in the European judicial area - A Green Paper on the application of EU criminal justice legislation in the field of detention. $\operatorname{COM}(2011) 327$ final.

35. Bourgon, G., \& Armstrong, B. (2005). Transferring the principles of effective treatment into a "real world" prison setting. Criminal Justice and Behavior, 32(1), 3-25.

36. Hepburn, J., \& Griffin, M. (2004). The effect of social bonds on successful adjustment to probation: An event history analysis. Criminal Justice Review, 29(1), 46-75.

37. Simon, T., \& Atkins, R. (1995). Prisoner transfer treaties: Crucial times ahead. In R. Atkins (Ed.), The alleged transnational criminal (pp. 69-86). Den Haag: Martinus Nijhoff Publishers.

38. Garcia, C., Esther Montero, P.D.T.E., Morar, I., Palmisano, R., Picciotti, V., Popa, S., Ravagnani, L., Albert, M., Gregorio, R., \& Durnescu, I. (2015). Obstacles and Solutions in the implementation of the FD 2008/909/JHA STEPS2 Resettlement: Support for Transfer of European Prison Sentences towards Resettlement. Project Report Steps2 resettlement. Retrieved from http://steps2.europris.org/wpcontent/uploads/2016/07/Annex-4.6.-Workstream-1-Obstacles-and-Solutions-in-the-implementation-ofthe-FD-2008909JHA.pdf

39. Robinson, D. G., \& Crow, I. (2009). Offender rehabilitation: Theory. SAGE London: Research and Practice.

40. Nauta, O., Van Aalst, M., \& Özgül. P. (2018). Evaluatie wet wederzijdse erkenning en tenuitvoerlegging vrijheidsbenemende en voorwaardelijke sancties (wets). WODC, Ministerie van Justitie \& Veiligheid. Retrieved from https://www.wodc.nl/onderzoeksdatabase/2847-evaluatie-wets.aspx

41. Aebi, M. F., Tiago, M. M.; Berger-Kolopp, L. \& Burkhardt, C. (2018). Council of Europe Annual Penal Statistics: SPACE I - Prison populations. Survey 2016. Retrieved from https://www.coe. int/en/web/prison/space 
42. Pakes, F., \& Holt, K. (2017). Crimmigration and the prison: Comparing trends in prison policy and practice in England \& Wales and Norway. European Journal of Criminology, 14(1), 63-77.

43. Van Dijk, J. (2011). Trends in Dutch prisoner rates: Regression to the mean or enduring exception? In E. Shea, \& H. Kury, (Eds.), Punitivity international developments Vol. 1: Punitiveness - a global phenomenon? (pp. 203-225). Brockmeyer.

44. Van Swaaningen, R. (2013). Reversing the punitive turn: The case of the Netherlands. In T. Daems, D. Van Zyl, M. Smith, \& S. Snacken, (Eds.), European penology? (pp. 339-359). Hart Publishing.

45. Dünkel, F. (2017). European penology: The rise and fall of prison population rates in Europe in times of migrant crises and terrorism. European Journal of Criminology, 14(6), 629-653.

46. Pratt, J. (2008). Scandinavian Exceptionalism in an era of penal excess. British Journal of Criminology, $48(1), 119-137$.

47. Pratt, J., \& McLean, T. (2015). Inspector Wallander's angst, social change and the reconfiguration of Swedish Exceptionalism. Punishment \& Society, 17(3), 322-344.

48. Statistisches Bundesamt (2017b). Bestand der Gefangenen und Verwahrten in den deutschen Justizvollzugsanstalten nach ihrer Unterbringung auf Haftplätzen des geschlossenen und offenen Vollzugs jeweils zu den Stichtagen 31. März, 31. August und 30. November eines Jahres - Stichtag 31. A ugust 2017 . Retrieved from https://www.destatis. de/DE/Publikationen/Thematisch/Rechtspflege/StrafverfolgungVollzug/Strafvollzug.html

49. Dünkel, F., \& Morgenstern, C. (2018). The monitoring of prisons in German law and practice. Crime, Law and Social Change, 70(1), 93-112.

50. Direction générale des Etablissements Pénitentiaires (2017). Rapport annuel 2016. Retrieved from https://justice.belgium.be

51. CPT (2017). Public statement concerning Belgium. Retrieved from https://rm.coe.int/pdf\%20 $/ 1680731786$.

52. Snacken, S. (2007). Penal policy and practice in Belgium. Crime and Justice, A Review of Research, $36(1), 127-215$.

53. Beyens, K., \& Roosen, M. (2017). Electronic monitoring and reintegration in Belgium. European Journal of Probation, 9(1), 11-27.

54. Maes, E., Mine, B., De Man, C., \& Van Brakel, R. (2012). Thinking about electronic monitoring in the context of pre-trial detention in Belgium: A solution to prison overcrowding? European Journal of Probation, 4(2), 3-22.

55. Pakes, F., \& Holt, K. (2015). The transnational prisoner: Exploring themes and trends involving a prison Deal with the Netherlands and Norway. British Journal of Criminology, 57(1), 79-93.

56. Bosworth, M., Franko, K., \& Pickering, S. (2018). Punishment, globalization and migration control: 'Get them the hell out of here'. Punishment \& Society, 20(1), 34-53.

57. Van der Woude, M., Barker, V., \& Van der Leun, J. (2017). Crimmigration in Europe. European Journal of Criminology, 14(1), 3-6.

58. Aas, K.F. (2014). Bordered penality: Precarious membership and abnormal justice. Punishment \& Society, 16(5), 520-541.

59. Melossi, D. (2013). The process of criminalization of migrants and the question of the European Union as a 'land of immigration'. In T. Daems, D. van Zyl Smit, \& S. Snacken (Eds.), European penology? (pp. 125-144). Portland: Hart Publishing.

60. Morgenstern, C. (2013). Remand detention in Europe. Comparative and pan-European aspects as elements of a wider European penology. In T. Daems, D. van Zyl Smit, \& S. Snacken (Eds.), European penology? (pp. 139-215). Portland: Hart Publishing.

61. Turnbull, S., \& Hasselberg, I. (2017). From prison to detention: The carceral trajectories of foreignnational prisoners in the United Kingdom. Punishment \& Society, 19(2), 135-154.

62. Van Kalmthout, A., Hofstee-van der Meulen, F., \& Dünkel, F. (2007). Foreigners in European prisons. Nijmegen: Wolf Legal Publishers.

63. Barker, V. (2017). Nordic vagabonds: The Roma and the logic of benevolent violence in the Swedish welfare state. European Journal of Criminology, 14(1), 120-139.

64. Statistisches Bundesamt (2017a). Strafvollzug - Demographische und kriminologische Merkmale der Strafgefangenen zum Stichtag 31.3.2017, Fachserie 10 Reihe 4.1. Retrieved from https://www.destatis. de/DE/Publikationen/Thematisch/Rechtspflege/StrafverfolgungVollzug/Strafvollzug.html.

65. De Bondt, W., \& Quackelbeen, L. (2015). The future of exchanging identification, security and social rehabilitation relevant information in the context of EU transfer of sentenced persons. STEPS2 resettlement: Support for transfer of European prison sentences towards resettlement. Retrieved from http://steps2.europris.org/en/documents/ 
66. Graat, J., Oude Breuil, B., van Uhm, D., van Gelder, E., \& Hendrikse, T. (2018). The Netherlands, part IV Dutch report 1. Europrisoners project report. Retrieved from https://euprisoners.eu/documents/

67. Tomkin, J., Zach, G., Crittin, T., \& Birk, M. (2017). The future of mutual trust and the prevention of illtreatment, Judicial cooperation and the engagement of national preventive mechanisms. Ludwig Boltzman Institute of Human Rights. Retrieved from http://bim.lbg.ac. at/sites/files/bim/anhang/publikationen/final_version_the_future_of_mutual_trust_and_the_prevention of_ill-treatment_1.pdf

68. Soeters, J., Hofstede, G., \& Twuyver, M. (1995). Culture's consequences and the police: Cross-border cooperation between police forces in Germany, Belgium and the Netherlands. Policing and Society, 5(1), $1-14$.

69. Banach-Gutierrez, J. B. (2013). Globalised criminal justice in the European Union context - how theory meets practice. New Journal Of European Criminal Law, 4(1), 154-167.

70. Klip, A. (2016). European criminal law: An integrative approach. 3rd Edition, Intersentia.

71. Neveu, S. (2013). Probation measures and alternative sanctions in Europe: From the 1964 convention to the 2008 framework decision. New Journal of European Criminal Law, 4(1), 134-152.

72. Asp, P. (2013). Harmonisation of penalties and sentencing within the EU. Bergen Journal of Criminal Law and Criminal Justice, 1(1), 53-62.

73. Hofmann, R., (2017). Flucht, migration und die neue europäische Sicherheitsarchitektur Herausforderungen für die EU-Kriminalpolitik. Springer VS, Wiesbaden.

Publisher's note Springer Nature remains neutral with regard to jurisdictional claims in published maps and institutional affiliations. 